Eis o parecer aprovado pela $6 .^{a}$ Comissão:

"Partindo da asserção de que a intransigência em manter rgorosamente a velha distinção romana entre Direito Público e Direito Privado vem gerando ,na literatura do Direito Administrativo, a multiplicação de "novidades", que só o esquecimento completo dos dogmas privatísticos autorizaria fôssem consideradas tais, conclui o ilustre professor Ruy Cirne Lima mostrar-se oportuno empreender o estudo dos institutos e figuras jurídicas do Direito Administrativo, em comparação com as espécies paralelas do Direito Privado, criando-se, destarte, um como Direito Comparado "ad intra", nesse setor importantíssimo da investigação jurídica. Como contribuição a êsse "desideratum", elaborou ensaios sôbre "Ato administrativo e ato jurídico privado" e "Domínio público e propriedade privada". Como a totalidade dos membros da Comissão não só tem conhecimento pessoal e direto dos têrmos da tese do professor Ruy Cirne Lima, como concorda, ainda, plenamente, com as conclusões a que, com. a habitual maestria, chegou o eminente jurisconsulto, deliberou a mesma Comissão encaminhar a aludida tese ao plenário do Congresso com a recomendação de que a aprove integralmente. Tratando-se por outro lado, de trabalho não muito extenso, resolveu, também, a Comissão dispensar o relatório acêrca da tese e designar um dos seus membros para, em plenário, proceder-lhe à leitura".

Cumprindo essa determinação, o relator passou a ler a tese do professor Cirne Lima, que mereceu integral aprovação do plenário.

\section{NATUREZA JURÍDICA DA CONCESSÃO DO SERVIÇO PÚBLICO}

Oswaldo Aranha Bandeira de Mello

Professor Catedrático da Faculdade Paulista de $\mathrm{Di}_{\text {- }}$ reito da Pontifícia Universidade Católica de São Paulo.

Capítulo I

\section{DO SERVICO PÚBLICO}

1 - A vida isolada do homem, é, em regra geral, impossível. Pela própria natureza, são os entes humanos impelidos a viver em sociedade. Além disso, percebendo as vantagens que resultam da cooperação dos seus semelhantes, não podem deixar de desejá-la. Temos, portanto, que a vida social é uma resultante dêsses dois ele-m mentos: necessidade e liberdade.

Daí, o dever de colaboração recíproca, concretizado no princípio de solidariedade, não só impôsto pela própria natureza, como, ainda, querido, por verificar-se que convém à vida em comum.

O meio exterior apropriado é fisicamente adequado ao desenvolvimento do nosso organismo, para êste percorrer o ciclo natural da sua evolução. Por sua vez, o meio social apropriado é psicològicamente adequado aos nossos sentimentos e aos nossos pensamentos, para se manifestarem e se aprimorarem.

Para que a vida em sociedade possa frutificar, exige a prática de certas atividades e, por outro lado, a abstenção de outras. Isto, é, tôdas aquelas atividades que contribuem para a vida social próspera devem ser praticadas, bem como devem ser evitadas tôdas as que lhe forem prejudiciais. Eis aí, a conclusão imposta: a união dos esforços individuais para a realização de fím comum, constituidor do bem da coletividade.

A expansão da personalidade humana exige, - e isso é de senso comum - a formação de várias sociedades, algumas naturais e outras convencionais, sendo, conseqüentemente, necessárias as primeiras e voluntárias as segundas. 
Embora ambas constituam meios para o sêr humano alcançar - fim, fôrça é distinguí-las como condição indispensável no primeiro caso, e, simplesmente, como fator aconselhável, no segundo. Aquelas compreendem as sociedades familiar, profissional, política e religiosa tuidas, enfeixam quantas sociedades privadas venham a ser constituidas por acôrdo de vontade entre os cidadãos e não sejam havidas
como contrárias à natureza humana.

2 - No campo social, é mister apreciarem-se as relações dos seres humanos entre si, dêstes com as sociedades, e das mesmas sode ação exclusivo, Cada qual tem atribuição própria, como campo de ação exclusivo, em atenção a finalidades peculiares. Mas, além cada qual, exuições, outras existem, refulgindo ao círculo particular de se faz preciso estaburge a complexidade dos casos mixtos, em que choque. Porém, é de bom a proeminência entre duas posições em choque. Porém, é de bom aviso não se confundirem competências concorrentes com competências privativas.

A solução do problema social está em solver-se a incógnita do justo equilíbrio a obter-se na relação estabelecida pela posição do homem em face da sociedade. À sociedade, cabe observar, nada mais que a reunião de homens para atingir o bem comum observar, nada a solução da incóonites. Assim, humana, que se resolverá pela no estabelecimento de uma equação quanto homem

Para se conseguir a eficácia họmem enquanto animal.

vel o aparecimento de um princíp dêsse "desideratum" é indispensáhumanas na melhor um princípio unificador, que dirija as atividades

${ }^{3}$ - A autoridade constituida, na sociedade política, resulta da unificador de um pom sociedade e consiste na organização de poder comum dos sus mista o bem

Existe para

zação, para salvagur a coletividade e só se justifica a sua organização, para salvaguardar o interêsse da comunidade, sendo as suas atividades condicionadas ao bem comum dos indivíduos que suas põem a sociedade política.

O que distingue esta, ou melhor, o Estado das outras coletividades é ser um poder supremo, isto é, possuir como qualidade essencial a soberania. Diz-se que um poder é como qualidade essencia a capacidade de auto-determinac̃o é supremo quando tem não só êle próprio, o seu campo de cípios da ciência jurídica de aça, respeitando, entretanto, os prinonipotência; daí je na confundir soberania com ora mencionada, pode sofrer as restrições voluntártrição necessária, a si mesmo.
Constituindo-se corporações políticas soberanas, são os Estados em princípio, iguais e, por isso, considerados, uns em relação aos outros, comunidades independentes.

Num certo território e sôbre o seu povo, em regra, portanto, só pode haver poder público titular da soberania, quer dizer, competente para a totalidade dos assuntos temporais de ordem política.

$\mathrm{E}$, embora muitas vêzes o exercício dêles se distribua entre outras entidades, ùnicamente o Estado fica com a capacidade de decisão em última instância, pois, a soberania é, por natureza, indivisível.

Entidade, abstrata, êle se traduz por fatos materiais tangíveis ou intelectualmente perceptíveis, constituindo uma unidade no espaço e no tempo, pois, é uma organização composta de indivíduos, mas possui caráter mais duradouro, e independente dêles, considerados "ut singuli", e que visa realizar o bem comum da coletividade.

Assim, embora dependa dos elementos humanos que o compõem para existir em dado território, forma um todo distinto dêles e com escopo definido, especial e exclusivo. É o núcleo de convergência e o ponto de partida das atividades levadas a efeito em atenção ao bem comum dos componentes da comunidade e participantes do caráter de identidade e permanência. Essa qualidade, de ser centro de atribuições e operaçôes na ordem moral e ser capaz de direitos e obrigações na ordem jurídica, o caracteriza como pessoa moral e jurídica, ou, melhor, como pessoa coletiva.

Como pessoa coletiva, o Estado distingue-se da pessoa física pois, ao contrário desta, é desprovido dos atributos próprios de inteligência e vontade, que the são peculiares. Êle, realmente, não é um ser consciente e livre, mas unidade composta de seres conscientes e livres, isto é, união formada de seres com os atributos de inteligência e vontade sob um poder unificador, em dado território, ligados através de relações de interdependência e solidariedade, visando ao mesmo fim. Em resumo, é um ser acidental constituido de relações entre seres substanciais para alcançar o seu bem comum.

4 - Examinando-se a natureza das cousas, cumpre dar a cad um o que é seu: a Cesar o que é de Cesar e a Deus o que é de Deus - e daí o termos a justiça nos seus múltiplos matizes: quer nas relações comutativas egualitárias, quer nas relações institucionais, distributivas. E a justiça nada mais é que a expressão do Direito, o qual rege as relações humanas na sociedade, fixando as condiçóes da conduta dos sêres que a integram.

Mas, êsse Direito não é o impôsto pela vontade da maioria, em que o bem comum se transforma na soma das vontades particulares, nem é o impôsto pela vontade de um só, em que o bem comum 
se transforma em entidade mitológica superior aos homens. O Di reito, de que se fala, é o obtido pelo exame da natureza huma pelo estudo das condicôes necessárias exame da natureza humana im. Destarte, as condições de vida socia homem atingir o seu pela própria natureza humana váspera são fornecidas sto é, o ser animal mas a peso não o indivíduo, essoa, isto é, o ser racional. Não vecialismo nem se anarquiza a sociedad individualismo. Não há sequer a ego anarquiza a sociedade pelo no domínio democrático se anonimato, expresso opressão da autocracia.

solução no império prestígio da autonomia da vontade, procura-se harmonizam império da natureza das cousas e, por êsse muitos, pelo solidarismos, substituindo-se o egoismo, de um ou de ção: o indivíduo está para tal, estabelece-se a seguinte proporpara a pessoa humana. E, is deu como razão declosão da o seu fim, pelo desenvolima o homem, como ente ra sociedade se seu fim, pelo desenvolvimento racional, atingi dos sentidos do indivíduo. A noção do bem

ficativa, - não se superpõe, - não é quantitativa, porém quali$\mathrm{Na}$ verdade a sociedade todos os predicados tem por objetivo facilitar a expansão feita com o intuito único, de servir a coordenação do bem comum é humanos que a constituem, de servir à coletividade ou, seja, aos sêres

O direito, que se apregôa, enfim, é o direito natural,
estujas o qual substitui o acaso arbitráriolhor, é a própria moral social, uma ordem social acaso arbitrário ou o determinismo necessário, sêres que compõat natural, decorrente da finalidade intrínseca por

edade.

exige esfôrço paciente, observação as abstratos da ciência jurídica humanos, dos costumes observação atenta e prolongada dos caracteres las in costumes da sociedade, do jôgo das leis e do

Assim, se concilia a imutabilidade dos principios cientificos fundamentais com a variac̃a o princípios científicos fun através do tempo e do espaço seus desenvolvimentos na aplicação. dindo, segundo as circunstâno. E, o direito natural, estável, presiceitos que lhe são complementas, a oscilação, do conteúdo dos preconstante adaptação, atendento e encerram o direito positivo, em a pressão do homem e do meio a razões históricas e geográficas e 5 - No Estado de Direito, há época.

específicas que competem Direito, há a distribuição de atribuições gãos pelos quais se atua. ao poder público, uno, entre os vários ór. paração dos poderes, até há bem pouco tempo clássica no direito constitucional. Hoje em dia, entretanto, ela vem sendo objeto d $\epsilon$ justas críticas, pois, na verdade, o poder público é uno, sendo diversas apenas as suas manifestações, caracterizadas por funções fundamentais.

Assim, não se pode dizer que os três poderes, legislativo, execurivo e judiciário, são órgãos do Estado, mas, que o poder público soberano, com funções fundamentais, se espraia através de vários orgãos que, devem estar coordenadas por um órgão superior, a quem compete unificá-las, firmando as diretrizes do conjunto.

Competências distintas não se misturam. Porisso, atribuições de natureza diversa cabem a órgâos coordenadores independentes. E êstes se integram no órgão supremo constituinte, de onde dimanam todos os poderes que lhes são atribuidos. Entendem os autores, em divergência, que essas funções fundamentais ora compreendem a atividade legislativa, coordenada pelo Parlamento, a atividade executiva, ou melhor, administrativa, coordenada pelo chefe do govêrno e a atividade judicial, coordenada pelo mais alto Tribunal do País ora desdobram a atividade executiva em atividade governamental e administrativa, cabendo àquela os atos de direcão e a esta os atos de execução, ambas, entretanto, coordenadas afinal no mesmo órgão; ora consideram a atividade judicial e executiva como partes da mesma atividade administrativa e, daí, só admitirem duas competências fundamentais: a administrativa e a legislativa, respectivamente coordenadas pelo Chefe da Nação e Parlamento.

Nenhuma dessas correntes dominantes no pensamento jurídico moderno, está com a razão, ao classificar as funções fundamentais do Estado, pois, na verdade, elas se reduzem às seguintes: administrativa e judicial.

Pela atividade administrativa, o Estado integra os princípios necessários à consecução de seu fím, de realização do bem comum de seus membros, de modo direto.

Compreende o estabelecimento de normas de caráter geral e sua aplicação por atos que a concretizam em face das situações particulares, devidamente fiscalizados e informados, sempre tendo em vista a integração dos princípios julgados necessários à realização do bem comum dos membros da comunidade política.

Pela atividade judicial o Estado reintegra os princípios considerados necessários à realização do bem comum dos seus membros, resolvendo situação contenciosa, provocada no processo de exteriorização do direito, pelo estabelecimento, mediante interpretação ou construção, do direito controvertido.

6 - Em virtude do Estado ser desprovido de atributos de inteligência e vontade, a realização das atividades necessárias à con- 
secução de seu fim é confiada a indivíduos, considerados seus agen tes, mas a êle imputadas, pois são praticadas em seu nome e inteAtinge pois, o Estado, coletivo, seu escopo especial e exclusivo, agentes públicos, no cumprimentogra, o seu fim diretamente por serviços levados a feito presto das respectivas atribuições. $O_{S}$ poder público, e no seu interêsse, exodo, são executados em nome do próprios da pessoa cou interêsse, e considerados, por consequiência

Entretanto há coletiva, política, a que são imputados. empreender diretamente, e ticulares que os executam então delega o seư cumprimento aos parterêsse, devendo-lhes, portam nome deles (particulares) e no seu incomo tais serviços são de caráter público e como próprios. Porém, exercem em virtude são de caráter público e os particulares apenas os velar pelo modo do de delegação da administração, cabe ao Estado coletividade Âs do exercício, salvaguardando o interêsse da atividade do Estado.

7 - O serviço público compreende a prestação de atos de utilidade jurídica, pelos indivídun ponde ao exercício de ofício público; encarregados, o que correscomodidade pela feitura de público; ou a prestação de verdadeira tição para isso oranizada, obra ou disposição de coisa, por reparprêsa pública.

O servico

às pessoas componentes dade consistir em atividades que satisfaçam ou à comunidade em sí, isto ć "pró, isoladamente consideradas, Em uma das hipóteses ó, isto é, "pró-cidadão" e "pró-comunidade". recebe as vantagens, o serviço é instituido em atenção a quem apenas, o bem comum, isto é, nervitra é criado tendo em vista, para a comunidade.

segundos the são, de de qualquer forma, oferecidos ao público, e os. sua disposição, para que se utilize impostos; aquêles são colocados à ver, ao passo que êstes êle é obrigado a ễles, conforme the aprousua vontade, mediante clac̃̃o. dade política, enquantoação. Uns, são condição de vida da sociede melhoria, enquanto outros são condição de aperfeiçoamento e

O serviço público pró-comunidade atende ao bem comum, ou terêsse individual. terêsse individual. Isso porque não pode ser individualizado, como a defeza nacional, cujo interêsse da coletividade se integra até com o interêsse do próprio Estado em si, embora êste seja meio ate com lizar aquêle fim; ou então porque não tem objetivos de satisfazer aos interêsses individuais, mas, entretanto, reflexamente se satisfazem, por lhes convir, a-pesar-de levados a efeito, apenas, tendo em vista a imediata conveniência da coletividade; "v. g.", certas medidas de polícia, de segurança pública ou de bem estar geral. Os serviços públicos pró-cidadão são aquêles que, atendendo ao bem comum, ou melhor, ao interêsse coletivo da comunidade, visam satisfazer o interêsse individual dos cidadãos que compõem essa comunidade, isoladamente considerados, seja porque êsse é o seu escopo primário, como o caso do transporte; seja porque a satisfação de ambos os interêsses - individual e coletivo - se confundem, "v. g.", as vias de comunicação.

8 - No exercício de suas atividades para realização dos serviços públicos, o Estado se utiliza, quando necessário, do poder de império sôbre as pessoas e do domínio eminente sôbre as coisas, em regime jurídico especial de prerrogativas incontrastáveis de mando, resguardados, é certo, os direitos dos particulares, segundo a ordenação jurídica dominante. Êsses processos são de aplicação direta e imediata com referência aos serviços públicos pró-comunidade, uma vez que são impostos ao público, e de aplicação simplesmente indireta e. mediata nos serviços pró-cidadão, visto que são oferecidos ao público, concorrendo em tal hipótese para facilitar a execução do serviço, pròpriamente dito, ou para assegurar a sua boa gestão.

Além de atividades para cumprimento mediato ou imediato dos. servicos públicos, realiza o Estado outros, que devem ser havidos como de caráter particular, constituindo, na verdade, meios indiretos. para atingir aquêles. Na realização de tais atividades o Estado se equipara aos súditos nas suas relações recíprocas.

Para consecução do seu fim, portanto, o Estado se utiliza de meios e modos adequados para isso, sendo que êsses meios e modos. necessários e próprios para execução de serviços públicos são havidos como públicos ao passo que são considerados como privados aquêles que servem para realização de sua atividade privada.

Ao poder público, no exercício das prerrogativas que lhe são. próprias como ente soberano, na consecução do bem comum, cumpre, sempre, alterar a organização e o funcionamento dos serviços públicos. e modificar o modo de desempenho dos atos públicos. Trata-se de atribuição personalíssima e decorrente de sua própria razão de existir, que jamais pode ser alienada, sob pena de considerar-se tal procedimento político e jurídicamente sem valor. Com referência à sua atividade privada, sujeita-se ao direito comum.

Os serviços públicos, destinados a satisfazer imediata necessidade coletiva, devem ser organizados tendo em vista especialmentea realização desinteressada de tal objetivo, sem o intuito de auferir. 
rendas, pois, em princípio, não tem finalidade lucrativa. Nada impede, jam cobertas, com despesas da prestação dos serviços públicos sea título de incentivo, uma parcel seus beneficiários, havendo assim, vico é que permite mo com prejuízo seja êle explorado com lucro, pelo custo ou mesmo com prejuízo, o que é apreciado pelo govêrno, atendendo a conveniências político-administrativas.

Ao contrário, as atividades privadas do Estado podem ter ob jetivos comerciais, embora seja desaconselhável exerça êle essas emprêsas, pois, as atividades privadas do Estado só devem existir como elemento para consecução de suas atividades públicas.

9 - Os meios de gestão são os procedimentos utilizados pela administração pública, para conseguir os elementos julgados necessários para o serviço atingir o seu escopo, a saber: homens, materiae dinheiro.

Os processos de gestão são os métodos utilizados pela administração pública na realização do próprio serviço, estabelecendo para tanto as condições havidas como mais convenientes, a saber: "regie"
"e concessão.

10 - Na realização do seu fim, o Estado exerce dupla ação jurídica e social. A ação jurídica visa a consecução das atividades de defesa externa e manutenção da ordem internação das atividades de paz na sociedade política, pela tutela interna, para efetivação da a consecução politica, pela tutela do direito. A ação social visa bem estar e das atividades tendentes a desenvolver as condições de des físicas, econômitamento coletivos, pela satisfação das necessidaA aça juricas e espirituais dos cidadãos.

blico. A outorga da tutela do direitouições privativas do poder púsua falência virtual, em virtu direito aos particulares, acarretaria a A ac̃o A ação social é levada a efeito pelo poder público concorrentemente $\mathrm{com} \cdot \mathrm{os}$ particulares, sendo que o primeiro, age, sòmente, em caráter "supletivo e complementar, isto é, com objetivo de suprir a falta ou deficiencia dos serviços afetos ao último, salvo, é claro, os casos em "que a natureza peculiar dos serviços ou razões de conveniência administrativa, tendo em vista interêsse público, por motivos compreensíveis, aconselhem a retir alçada livre dos particulares, para certos serviços, em princípio,

Assim, a ação social para serem avocados pelo Estado. distintas: as em que os particulares duas ordens de atribuições e as que devem ser os particulares concorrem com a administração, . que devem ser avocadas por esta última. Com referência às prí, meiras, incumbe ao poder público, em regra, apenas zelar por sua execução, fomentando a atividade dos particulares, ao passo que, com referência às últimas, como norma, há a substituição da atividade livre dos particulares pelo poder público. São respectivamente serviços impróprios e próprios do Estado ou, melhor, serviços de utilidade pública e servicos públicos. Êstes só podem ser exercidos pelo Estado ou seus delegados e destinam-se ao público, mediata ou imediatamente; aquêles devem ser exercidos pelo Estado sòmente na falta ou deficiência dêles por particulares, incumbindo-lhe, em regra, apenas, animá-los, incrementando e incentivando, senão mesmo exigindo, quanto possível, o seu exercício por terceiros. Os chamados "serviços impróprios do Estado", isto é, de utilidade pública, são servicos correspondentes a prestações privadas, mas, dado o fim a que são dirigidos, e o número elevado de pessoas que nêles são interessadas, pertencentes à coletividade, são submetidos a disciplina jurídica especial, mesmo porque, na falta dos particulares poderem exercer tais serviços, deve o poder público provê-los.

Tais serviços, por isso, são exercidos até mediante certa regulamentação do Estado. Constituem atividades privadas, sujeitas à sua ingerência.

A simples regulamentação, portanto, da prestação de determinada atividade, em alguns de seus aspectos, não significa, em considerála pública, mas, apenas, de utilidade pública. A regulamentação, que implica em considerar o serviço como público, é a sua retirada do comércio comum, com o estabelecimento de sua exploração pelo Estado ou seus delegados. Enfim é preciso que se enquadre nos processos de execução de direito público.

Os casos cuja natureza peculiar indica que devem ser avocados pelo Estado, são fáceis de serem discriminados. Enfeixam os serviços que, para seu cumprimento exigem, ao menos mediatamente, o exercício do poder de império, próprio dos sêres soberanos e dos entes que constituem seus desdobramentos, ou o uso de bens do domínio das entidades políticas. Os casos em que a conveniência administra tiva, tendo em vista especial interêsse coletivo, aconselha sejam alguns serviços avocados pelo Estado, são de difícil classificação, pois, só o exame das circunstâncias objetivas é que convence ou não da necessidade de retirá-los da ação livre dos particulares e sujeitá-los a regime de contrôle. Considerar, por conveniência administrativa, certo serviço como público, é atribuição discricionaria do Estado.

As atividades dos particulares que devem ser, por conveniência administrativa, consideradas como serviços públicos, são as que afetam, de certa maneira, a defesa nacional ou a ordem pública, exemplificativamente, pela sua posição estratégica ou facilidade de divulgação ao estrangeiro, os serviços de telégrafo, rádio, etc., ou, então, as que refletem diretamente no interêsse da coletividade, nas suas condições de bem estar, pela circunstância de disfrutarem, de algum 
modo, monopólio de fato, a saber: a) - pela limitação de suas fontes de suprimentos; b) - pela falta de concorrentes, em virtude do caráter do serviço, que exige grandes capitais e tem campo de ação relativamente restrito; c) - pela dificuldade de encontrar locais de depósito, estações, etc., vantajosos para a instalação do serviço e. para o público; d) - pelas condições em que o produto ou o serviço é usufruido ou prestado; e) - pela inconveniência de concorrência; f) - pela segurança coletiva; g) - pelo abuso dos negociantes que, sem a avocação e fiscalização na gestão pelo Estado, têm possibilidade de abusar e efetivamente o fazem.

11 - As funções públicas da atividade jurídica são, em princípio, indelegáveis, pois pela própria essência, constituem atribuições exclusivas do poder público e, portanto, devem ser executadas diretamente pelo Estado. As emprêsas públicas da atividade social, em virtude de serem exercidas pelo Estado em caráter supletivo e complementar ou em conseqüência de avocação, dada a natureza especial da forma de exercício de alguns dêles ou motivos de conveniência administrativa, tendo em vista especial interêsse público, podem ser conferidas pelo Estado a pessoas naturais ou jurídicas de direito privado, quando não the parecer oportuno explorá-los diretamente.

Só se pode delegar a terceiros certos serviços da atividade social quando o particular, na sua exploracão, possa auferir proventos, portanto, serviços industrializáveis e, demais, não sejam daqueles: que são impostos aos indivíduos, mas simplesmente colocados à sua disposição, para que dêles disfrutem quando entenderem conveniente. Isso porque, no primeiro caso, faltaria o fator fundamental para atrair a atenção de terceiro e harmonizar o seu interêsse com o do Estado de conseguir adequada organização e funcionamento tão perfeito quanto possível, do serviço delegado. $\mathrm{E}$, no segundo caso, haveria o inconveniente, perturbador da própria ordem social e em especial da segurança individual, de entregar-se a terceiro o exercício de atividade cujo desenvolvimento direto exige a constante coação sôbre o particular, no cumprimento de competência peculiar a uma autoridade. Não devem ainda, ser concedidos os serviços que se relacionam com a defesa nacional e a ordem pública, a saber: as estradas de ferro estratégicas, o serviço de correio.

O desenvolvimento de uma cidade depende, em grande parte, do sistema dêsses serviços públicos industriais, organizados e funcionando em forma contínua, regular, sem discriminacão pessoal de usuários e em condições satisfatórias. São serviços necessários para se levar vida consentânea com a civilização atual e dificilmente dispensáveis um dia sequer, pelos prejuízos de ordem econômica e social que acarretariam ao público. Tanto industriais como comerciantes, opew rários manuais como trabalhadores intelectuais, servem-se dêles.
Tais serviços são de vida estável, mudam de gerações em gerações e não de estações em estações do ano, sendo relativamento suas transformações, pois, o seu progresso decorre não se alteram sefundos assinalados nos avanços das ciencias. Eles não se alteram sée gundo os gostos ou as imposiçóes da moda. Constituen ina.

e não formas comerciais. Têm fim altruista e não egoincipalmente,

Esses serviços de caráter industrial compreendem principal das ferroas comodidades seguintes: a) transportes terrestes, a fluvial por meio vias, onibus, metros, bondes; aquático, marítimo e fluvial por melo sub de embarcações apropriadas; aéreo, pelos aviốes e bááci de áleo, gaz solo, utilizando-se de canalizações, para condução de água, oleo, gaz soscoamento de detritos; b) comunicaçóes e outras necessidades e correspondência postal, telegráfica, radiográfica feitas em forma de corresponder luz e energia, telefônica; c) - fornecimento de agua, calor, frio, hutisfaca ade pelas comodidades da água, gaz e eletricidade; d) - satisjaça adepelas comidiantares fundamentais, como usinas pas quada das necessidades almentá várias classificações feitas pelos esteurizadoras, matadouros etc. Há varias classificaçónatia e completa critores. Nenhuma, todavia, é absolutamente satisfatória e completa cendo de carater enunciativo e náo taxativo. sendo de caráter en virtude do crescimento da população e, consedia, êsses serviços em virtude do crescimaior densidade de habitantes qüentemente, das cidades, originando maior drabalho, forçando quentemente impelindo à divisão intensa do trabalho, forc nas zonas uréces sua satisfação, imponalterações da tecnica da vida e dos locais, de produtos cujo consumo do ainda a colocação, em diferentes locais, de prodo produzidas em é necessário à coletividade e, assim, as comodidades são produzidas ér. escala, ofecidas ao público, por organizaçoes especializadas, a que têm por objetivo a pridas em determinada época, segundo o esdadas as necessidades sentidas em determinada épos imperativos tado de cultura da sociedade, aferido êsse estado pelos imperativos ambiemtes do homem e do meio.

Não existem e não podem existir contornos precisos estabelecerviços públicos, como dos de utilidade púcendo a esfera tanto dos privados. À medida do evolver das blica, como, ainda, dos privados. A medixados na políticas, êsses serviços saem de uma zona para sere conteudo variá outra. Sem dúvida, constituem conceitos fixos, mas de conteudo variá vel Variável segundo o grau de civilização e progresso do Estado, as vel. necessidades do povo e as con entre muitos dêles, em cuja linha de mesmo uma zona crepuscular entre muí as circunferência as esferas se tangenciam interpenetrandoms.

dúvidas classificacóes doutrinárias e legais existente.

2 - Enquanto os serviços públicos da atividade jurídica são 位 executados, em princín geridos pela atividade social que competem ao Estado, podem por via de delegação do 
poder público para o exercício dessa atribuição. Na primeira hipótese socialização e na segunda diretamente pelo poder público - temos a culares em virtude de delegótese - exploração do serviço por particessão.

Após a Revolução Francesa, sob a influência dos preceitos vidualistas que a informaram, predominfuencia dos preceitos india concepção de que o Estado predominou, em as naçôes civilizadas, serviços da atividade justificava fôssem avocadas para si tais nas duas hipóteses em que se cício aos particulares, mediante si tais atribuições, delegar o seu exera época em que imperava A grande que imperava o princípió do "laissez faire, laissez passer". contemporâneo, que se viu profunda transformação no pensamento tes do Direito, e por conseguinte, imbuido das concepções socializanà intervenç̃o direta do Eominado pelas doutrinas favoráve economia dirigida.$$
\text { Contra a adminis }
$$

se podem levantar várias objecõéta do Estado nos serviços públicos, gar, a sua incapacidade para exóes. Assim, se alega, em primeiro lulhe as necessárias doses para explorá-los em consequêencia de faltarque vão suroindo por dicitiva e adaptação às circunstâncias ação rapida ante as situacões do desempenho do serviço o que exige. gar se argumenta haver nacoes objetivas aparecidas. Em segundo lupessoal, pois, ele age por ins suas emprêsas, deficiência de interêsse têm, nos neócios, por intermédio de representantes, os quais não mente atingidos por êles. Além disse que os particulares imediatainfluências políticas, sendo difícil tamo estão sujeitas tais emprêsas á afim de se impedirem abusos de divembém sua rigorosa fiscalização nientes são mais sensíveis segundiversas naturezas. E êsses inconvëço e, principalmente, quando h́́ o grau de complexidade do servi-

Entretanto, por quando ha inversão de grandes capitais. do por concessão, em regra, tem fôrça é reconhecer, o serviço exercinário que procura satisfazer tem o seu fim deturpado pelo concessioções gananciosas, em detrimento que exclusivamente as suas ambiser do serviço. Demais, a fiscalizã bem estar coletivo - razão de sos dos concessionários, é muito difícil poder público, contra os abucuram estabelecer o máximo de tifícil e dispendiosa, pois êstes proprocurando por to maximo de transtornos à ação do poder público, Há serviços que convém mejam, fugir à sua interferência controladora. mais interessantes quando exam socializados, ao passo que outros são escolha dos métodos, quanto à form por concessão. Na verdade, a de determinada atividade to a forma de cumprimento pelo Estado, objetivas e à natureza dos social, varia em atenção às circunstâncias.
Caberá à regulamentação de serviços públicos acautelar as crín ticas acima apontadas contra ambos os sistemas. Prescreverá que a execução de tais serviços, quando exercidos diretamente pelo poder público, seja feita sob regime especial de autarquia e, portanto, independente das influências burocráticas e políticas e debaixo de ação de pessoa interessada no êxito da emprêsa. Estabelecerá que a prestação dêsses serviços, quando desempenhados por concessão, seja feita mediante completa fiscalização do poder público, pela repartição competente, e os seus dirigentes sujeitos a severas medidas punitivas no. caso de excessos de orientação da emprêsa ou na defesa dos seus interêsses. Além disso, poderá, em ambas as hipóteses, optar pela so- ciedade de economia mista que consiste em participar o poder público como sócio de emprêsa particular concessionária de serviço público, tendo maior ou menor ingerência, conforme o capital nela invertido, quando poderá ocorrer preponderância da riqueza pública ou privada, segundo a orientação política-administrativa julgada mais aconselhável, em função do objetivo que sugeriu a exploração do serviço público por concessionário constituído em emprêsa de economia mista. Em lìnhas gerais, portanto, a orientação no assunto poderá ser fixada. Porém, a solução definitiva deverá competir à entidade política que tiver a atribuição do serviço, pelo exame cuidadoso dos casos concretos.

Dada a intervenção muito intensa, nos países latinos, dos políticos na atuação do Govêrno, prejudicando os interêsses coletivos em proveito das conveniencias partidárias, nos parece preferível o regime de concessão ao de exploração direta pelo Estado, mesmo sob forma autárquica, dos serviços públicos de sua atividade social de caráter industrial. Mais fácil será se encontrarem nesses povos "equipes" de funcionários dedicados e hábeis que exercerão convenientemente a fiscalização dos serviços concedidos, do que conseguir-se organização satisfatória do poder público para diretamente gerir tais atividades, de forma que essas reparticões fiquem alheias ao bafejo da politicagem ou do emperramento burocrático. A socialização deve ser usada apenas como último recurso, quando a fiscalização dos serviços concedidos vier de todo a falhar. Na verdade, preferimos constitua antes uma ameaça contra possíveis abusos dos concessionários, do que um processo normal de execução do serviço. A sua previsão é imprescindível justamente para tais circunstâncias. Porisso, de regra, cumpre ser em potência para se atualizar em casos excepcionais, sòmente.

A sociedade de economia mista, se adotada, também melhor atenderá ao interêsse público, ao nosso ver, se nela prevalecer o capital particular, não constituindo, portanto, uma fôrça disfarçada da socialização, mas, ao contrário, emprêsa realmente de natureza privada. Em casos esporádicos, em que urge maior domínio do poder pú. 


$$
-872-
$$

blico, êle absorverá, então, a emprêsa, utilizando-se dos processos de direito público cabíveis.

Sempre, a socialização, absoluta ou relativa, do serviço da atividade social de caráter industrial, deve constituir medida de exces são, usada em casos excepcionais. $O$ instituto nessa eventualidade, vale mais como arma possível de ser empregada, portanto como atuação preventiva de coerção psicológica sôbre os concessionários.

\section{Capítulo I}

\section{DA CONCESSÃO DE SERVIÇO PÚBLICO}

13 - Concessão é o ato administrativo pelo qual poder publico incumbe a uma pessoa, natural ou jurídica, de exercer um ser viço público. Embora continue a ter o caráter de serviço público viço publico. Embora continue a ter o caráter de serviço público, é
âle exercido em nome e por conta e risco do concessionário.

14 - Coloca-se o concessionário no lugar do concedente, pois o serviço é próprio do Estado, exercendo-o por delegação. Atendendo razões de oportunidade política, ao invés de gerir diretamente o serviço, o Estado o faz por intermédio do concessionário havido o serviço, o Estado o faz por intermédio do concessionário, havido como capaz de desempenhá-lo satisfatòriamente, o qual, afiança, mediante as cautelas julgadas necessárias, assim proceder. Há, na concessão, a outorga ao particular, do exercício de serviço público de competência do Estado. Portanto, tal outorga é, e não pode deixar de ser, condicional, temporal e pessoal. A concessão, na verdade, é um simples processo técnico de execução de serviço público, de acôrdo com as exigências dêste. O serviço público delegado, deve ter, como o serviço público levado a efeito pelo Estado, o objetivo principal de atender ao interêsse coletivo, pois não seria admissível essa forma de exploração, se tal garantia não existisse.

15 - Ao concessionário são atribuidas as prerrogativas de exercer poderes peculiares aos entes políticos, necessários ao desempenho do serviço e de cobrar taxas, denominadas tarifas, dos usuários, como contraprestação dos serviços a êles fornecidos, tudo na forma e condições em que foram outorgadas essas faculdades.

16 - Pelo fato de incumbir o concedente ao concessionário da execução de um serviço público e, mais, dêste aceitar tal incumbên cia, nascem dêsse ato jurídico - conar dal incumbênî́o e obrigacões rếprocoso - concessão de serviço público - diconcessionário o direião público, assegurada a seu favor uma equação financeira estabelecida por ocasião da outorga da concessão cabe ao concedente o direito de obrigar o concessionário a executar

$$
-873-
$$

o serviço público, no interêsse da coletividade, segundo organização funcionamento mais convenientes para se atingir tal fim.

17 - Mas, o fato de criar direitos e obrigações, não constitui caraterístico suficiente para extremá-la de outros institutos jurídicos de cujos atos decorrem também, direitos para as partes, e não só direitos como obrigações.

Por não atentarem nisso, há autores que sentem dificuldades em especificar a concessão, distinguindo-a de outros institutos jurídicos, estabelecendo nesse terreno, verdadeira balbúrdia, dando conceito genérico ao instituto da concessão, dentro do qual cabem vários atos jurídicos que não devem ser compreendidos.

Os autores franceses e alemães oferecem noção mais restrita da concessão, pois a distinguem, apenas, em concessão de uso, obras e serviços públicos, ao passo que os italianos e alguns espanhois nela incluem, entre outras, a concessão de prêmios, de função pública e de "status" jurídico.

No presente estudo só nos interessa a concessão de serviços públicos e neste sentido tal expressão vem empregada.

\section{Capítulo III}

\section{DA NATUREZA DOS ATOS JURIDICOS}

18 - A elaboração de regras jurídicas, com a conseqüente criação de situações jurídicas pressupõe a prática de atos pelas pessoas de direito e havidos, portanto, como atos jurídicos, os quais consistem em manifestação de vontade daquelas pessoas, acarretando modificações diretas ou simplesmente declarações no ordenamento jurídico existente, para satisfação de determinados interêsses, pela formação de relações jurídicas.

Logo, o ato jurídico é manifestação de vontade, que, solicitada pelos motivos, delibera, ante a concepção e execução de certo assunto, para satisfação de determinado interêsse. E' formado tendo em vista as causas que influem na exteriorização de qualquer ato das pessoas, a saber: causa eficiente, que é o sujeito manifestante da vontade, causa final, que é a meta pela qual o ato solicitado pelos motivos foi praticado, causa material, que é o bem, cousa ou prestação, objeto do ato, e causa formal, que é o modo pelo qual o bem, coisa ou prestação se constitui objeto do ato, isto é, se torna o conteúdo da regra jurídica. As causas formal e material são elementos intrínsecos do ato jurídico, enquanto que as causas eficiente e final são elementos extrínsecos do ato jurídico.

27 - R. D. - 2.0 Vol 
Todo ato jurídico pressupõe sujeito capaz, objeto possível, conteúdo legítimo e fim adequado do agente e do próprio ato.

19 - A classificação dos atos jurídicos pode ser feita tendo em vista a relação jurídica em si ou tomando em consideração os efeitos dela decorrentes.

20 - Os atos jurídicos em si se dividem em atenção aos elementos intrínsecos, causas material e formal, ou melhor, ao objeto e a conteúdo da relação jurídica ou em atenção aos elementos extrínsecos, causas eficiente e final, ou melhor, à vontade das pessoas jurídicas, físicas ou coletivas que integram a formação de relação jurídica e a meta que visam alcançar e constitui motivo, portanto, da relação jurídica.

21 - As regras jurídicas, em relação às causas intrínsecas, compreendem o objeto e o conteúdo dos atos jurídicos, pelo qual produzem determinado efeito, ocasionando modificaçóes no ordenamento jurídico existente e a conseqüente produção de determinada situa ção jurídica.

Essas alterações podem dizer respeito a preceitos objetivos ou subjetivos, isto é, a preceitos de caráter geral e impessoal ou especial e pessoal, que como elementos constituidores de dado ordenamento jurídico acarretam imediatamente a criação de situações jurídica jurídico acarretam imediatamente a criação de situações jurídicas correspondentes a êles, ou, podem dizer respeito, simplesmente, à atribuição de preceitos objetivos, não aplicáveis de "motu proprio", a determinadas pessoas, criando a favor delas situações jurídicas também objetivas. Assim, considerando-se as regras jurídicas em relação às causas intrínsecas, os atos jurídicos se dividem em atos objetivos, atos subjetivos e atos-condiç̃̃o.

$O$ ato objetivo é o que formula regras de direito geral e impessoal e permite o estabelecimento, em conseqüência, de situacões jurídicas gerais e impessoais, ambas de caráter abstrato. $O$ ato subjetivo é o que formula regras de direito especial e pessoal e estabelece, conseqüentemente, situaçóes especiais e pessoais, ambas de caráter concreto. O ato-condição é o que atribui às regras objetivas, não executáveis de pleno direito, situações objetivas, tornando assim aplicáveis as regras objetivas pelo investimento de determinadim aplicaa situações objetivas decorrentes daquelas. Portanto, mediante ato de extensão especial e pessoal se estabelece aplicação de regras gerais e impessoais e a conseqüente criação de situações jurídicas correspondentes para determinados sujeitos de sireito juridicas corzação de tais regras abstratas.

O exemplo clássico de ato objetivo é a lei. Mas há outros atos. objetivos, tais como os estatutos das sociedades privadas, que estão, com referência aos seus associados, na posição da lei, pròpriamente. dita, com referência aos súditos de dada entidade política.
Caraterístico de ato subjetivo é o contrato, cuja aplicação muito orande no direito civil e comercial fez com que se pensasse constituir instituto alheio ao direito administrativo. Porém há contratos de direito internacional e administrativo lavrados entre as entidades políticas entre si ou firmado entre entidades políticas e particulares. Como à lei do direito civil e comercial se chamou de convenção e estatuto, ao contrato de direito internacional e administrativo se denominou tratado e acôrdo.

A natureza das coisas, entretanto, se não altera pela mudança de nome.

O tipo de figura jurídica que explica o ato-condição é o casamento. Mediante acôrdo de ambas as partes, se institui a família nos têrmos da legislação em vigor, isto é, nos moldes traçados pelo ato objetivo que regula a matéria, cuja aplicação aos cônjuges se dá pelo ato-condição do casamento. Outro exemplo é a nomeação dos funcionários, que pelo acôrdo de ambas as partes, governantes e particular, determinada pessoa se investe em cargo público, para agir em nome e por conta do Estado, na participação da atividade dêle de realizar o bem comum da sua população, tudo conforme os textos legais imperantes, isto é, nos moldes traçados pelo ato objetivo que regula a matéria, cuja aplicação a certo particular se dá pelo atocondição da nomeação.

22 - As regras jurídicas, em atenção às causas extrínsecas, compreendem o agente manifestante da vontade e a meta que se procura alcançar e, porisso, dá aso àquela manifestação. A manifestação da vontade do agente tendo em vista determinado fim pode ser unilateral ou convencional.

A manifestação unilateral é singular, quando formada pela vontade de uma só pessoa, e plural quando formada pela vontade de várias pessoas. Em ambos os atos unilaterais, singular e plural, a vontade, como é óbvio, deve deliberar, solicitada pela mesma causa final. $\mathrm{Na}$ hipótese do ato unilateral singular, o interêsse é uno e na de ato unilateral plural deve ser idêntico, isto é, cumpre haver conjugação de interêsses, e, por conseguinte, as causas material e formal, também, não podem ser diversas.

A manifestação convencional é aquela formada pela vontade de dois agentes ou grupo dêles que concorrem para a integração do ato, pelo acôrdo entre êles estabelecido para satisfacão de interêsses opostos. A oposição pode existir apenas quanto ao fim do ato, sendo idênticas as causas intrínsecas dela, mas pode existir, ainda, não só quanto ao fim, como, também, o chamado ato-união, ato recíproco ou ato-acôrdo e, no segundo, temos a figura conhecida do contrato.

Como exemplo de manifestação unilateral singular, está o testamento e como exemplo de manifestação unilateral plural está a lei 
nos regimes democráticos, elaborada pelas Câmaras e Ministérios e
promulgada pelo Chefe da Nação casamento pelo Chefe da Nação. A figura típica de ato-união é o são idênticos para amjeto e conteúdo, isto é, causas material e formal, são idênticos para ambos, a saber: constituição de certa família, emfins diferentes "verbi o homem para verbi gratia": a mulher para obter amparo moral e salientamos a consolidar situação financeira. Como tipo de contrato, salientamos a compra e venda, pelo qual o comprador quer o objeto e o penda têrmos do conteúdo estado na relação jurídica, conteúdo estabelecido preço do objeto vendido nos têrmos, também, do conteúdo estabelecido na relação jurídica, e querem êsses bens para objeto çâ de interêsses díspares, como sejam para utilizar-se do objeto na ampliação da sua indústria.

Embora aparentemente possa parecer inexistir interêsse na indagação da causa final das relações jurídicas, estudando-se mais a fundo o problema, se verifica o interêsse geral em se descobrir a causa linal da vontade de cada um dos sujeitos da relação jurídic se pode verificaróprio instituto jurídico. Pois, só pela sua apuraçãa se pode verificar se houve, ou não, abuso no exercício do direito por uma das partes integrantes da relação jurídica, discutindo-se, se gundo a concepção subjetiva, a ocorrência da má fé no seu deseobjetiva, a ocorrência de prejudicar a outrem, ou segundo concepção lar e anormal, ocôncia de desvio do seu fim, pelo seu emprêgo irregudicou a terceiro sem apreciável provitente a má fé, desde que preju-

apreciável proveito para o sujeito ativo.

$O$ ato objetivo é de natureza simples e se apresenta na produção do direito a que se propõe de forma pura. Já o ato-condição pressupõe ato-objetivo que êle particulariza. E no ato-subjetivo a complexidade é maior, pois que, além das regras pessoais e ciais que o caracterizam, êle traz, sempre regras pessoais e espeplemento, certas regras impessoas sempre, em seu bojo, como comato-condição. Assim, além da situac̃̃o gerais, particularizadas por êle envolve situac̃̃o jurídica da situação jurídica especial e pessoal, e deveres de ordem concra geral e impessoal, isto é, além de poderes

vas dentro de certa meditas permitem o estabelecimento đe regras subjetisiderados como de ordem áblenas, pois, há princípios por ela conrespeitados nos atos subjetivos, no e bons costumes que devem ser tivos, ademais existem outras res têrmos fixados pelos atos objefalta de regras subjetivas, como dias objetivas que têm aplicação na guinte, o campo de ação dos a to disposições supletivas. Por conse perativamente de ação dos atos subjetivos se encontra limitado im* perativamente por certas regras objetivas denominadas cogentes completado, subsidiàriamente, por outras regrás objetivas denominadas dispositivas.

Qualquer contrato, além das regras subjetivas que criam tal relacão jurídica, compreende as regras objetivas imperativas, regendo obrigatòriamente tôda relação contratual nos têrmos da legislação vigente, disciplinadora da matéria, e se completa por regras objetivas suplementares dispondo subsidiàriamente, na falta de preceito contratual, sôbre certos aspectos da aplicação de tal relação jurídica.

23 - Qualquer das modalidades das regras jurídicas, consideradas em si com referência ao seu objeto e conteúdo, isto é, os atos objetivos, subjetivos e condição, pode ser expressa por atos unilaterais, singular ou plural, pois, êstes têm aplicação genérica. Já com os atos convencionais se não dá a mesma cousa, visto que êles têm aplicação específica, assim, o ato-união só se manifesta como ato-condição, enquanto que o contrato só se exterioriza como ato subjetivo.

24 - Há atos unilaterais cuja manifestação da vontade fica subordinada à manifestação de outras vontades unilaterais, que constituem pressuposto ou condição suspensiva ou resolutiva daquela. Como, porém, essas vontades não se integram, constituem atos jurídicos independentes, e de forma alguma se confundem com ato unilateral plural ou com os atos convencionais: união e contrato. Nesta categoria podem ser mencionadas a admissão e autorização, em que ao ato da administração se pressupõe ato do administrado requerendo a efetivação dêles. Aquela consiste em ato administrativo vinculado pelo qual, reconhecidos no particular qualidades e requisitos prefixados, se lhe outorga fruição de serviço ou o uso de bem público, e esta em ato administrativo discricionário pelo qual se permite ao particular exercer atividade que a lei declara proibida, salvo assentimento em contrário da administração.

25 - Os atos jurídicos inferiores constituem, na verdade, execução de regras jurídicas superiores.

Essa execução se verifica pelo exame das escalas em que se encontram agrupadas as regras jurídicas. Os atos executivos são execuções de atos legislativos, como êstes o são de atos constitucionais. A execução material, entretanto, é o têrmo final da execução das regras jurídicas e o estágio último da sua concretização, pois, que as manifestações da vontade pressupõem, para sua efetivaçã̃o, a prática de atos materiais que asseguram a realização do direito.

Essa execução, entretanto, pode ser levada a efeito não só para exteriorização última de atos regras pessoais e especiais de caráter concreto, como também de atos regras impessoais e gerais de caráter abstrato e sem passar por aquela situação, quer dizer, diretamente do máximo de abstração ao máximo de concretização. 
A atividade material, quando elemento para execucão dos atos jurídicos, é considerada, como êste, atividade de realização do direito, entrosando-se, como parte essencial das regras jurídicas, isto é, como fator indispensável para sua completa exteriorização. Êles são o cumprimento de poderes e deveres contidos nas situações jurídicas representantes das regras jurídicas. Assim, a realização do direito que se inicia com o fenômeno psicológico interno da sua concepção, termina com o fato físico externo da sua realização material

26 - Os efeitos decorrentes dos atos jurídicos podem beneficiar, de forma direta, apenas a determinadas pessoas, particularmente, por elas visados ou estender as suas vantagens, indeterminadamente, às pessoas que compõem certa coletividade. Assim, envolvem atos de caráter particular, cujo objetivo é satisfazer imediatamente os interêsses das pessoas em jôgo ou atos de caráter coletivo cuja preocupação imediata é a de defender os interêsses dos integrantes da comunidade social. Aquêles são próprios nos indivíduos e êstes são peculiares dos entes políticos.

Em consideração, portanto, às partes beneficiadas pela relação juridica, referente esta particularmente ao sujeito ativo e passivo ou à coletividade, independe das pessoas que integram o ato jurídico, as regras jurídicas se dividem em públicas e privadas. Públicas são as relações jurídicas das entidades políticas entre si ou delas com os particulares, tendo em vista imediatamente o bem comum da população e mediatamente, apenas, o bem individual das partes relacionadas, relações cujo fim é a realização da justiça geral, mediante o emprêgo, se preciso, de método de constrangimento, ou melhor, de processo de autoridade, que constitui, afinal, o elemento próprio do Estado para consecução da sua razão de ser. Privadas são as relaçôes jurídicas de particulares entre si ou dêles com as entidades políticas, tendo em vista imediatamente o bem individual das partes relacionadas e mediatamente, apenas, o bem comum, da população, relações cujo fim é a realização da justiça comutativa e, por conseguinte, mediante o exercício de poderes iguais ou eqüivalentes em processos de economia própria, para satisfação dos seus interêsses peculiares.

De um direito público pode irradiar-se faculdades de direito público e de direito privado, segundo os interêsses que são protegidos pela ordem jurídica.

A organização e funcionamento de um serviço público, exercído por terceiro, são condicionados ao interêsse público, pois, o concessionário é um simples delegado do concedente. Destarte ao concessionário se faculta o exercício de poderes peculiares nos entes públicos para efeito de atingir a realização do serviço concedido, na sua organização e funcionamento. Por outro lado, pelo ato público da concessão, se assegura ao concessionário, muita vez, a prerrogativa de ex sa a de venda de mercial relacionada ao objeto da concessão, tal seja a de gaz. Ora, mercial relacioncessionário de serviço de fornecimento de tais atividades fogões por conceste e terceiros no desempenho de tais

as relações entre êle e terceiros no príp do direito privado.

\section{Capítulo IV}

\section{DA NATUREZA DO ATO JURIDICO -}

CONCESSÃO

\section{$\$ 11^{\circ}$ - Considerações Preliminares}

27 - A natureza jurídica da concessão de serviço público tem do objeto das mais vivas polêmicas, e, até hoje, os autores discutem sido objeto dam haverem conseguido harmonizar as opindo se procura - assunto, sídia é de tal monta que o debate começa quando se p̀̀ afites. A dissídia é de tal moutrinárias dominantes, atend

idades essenciais das opiniões emitidas na matéria.

A classificação dessas doutrinas se pode fazer, em atenção clasA cério histórico do seu aparecimento ou tendo entais. A classifiificaça sistemática dos seus elementos tundamentíc. da matéria, sifiço sistemática satisfaz melhor a exposição cientifica da mas para a cação sistemática satisfaz agrupamento das doutrinas basicas para a porquanto considera no agrupa Entretanto, nada impede, e, de certo sua enunciação razões lógicas. Entrés a separação das correntes mesmodo, até é aconselhável, que, após a separação das corias, cogitantras, se faça, dentro de cada grupo, a exposição das teóírio jurídico. to-se da ordem cronológica do seu surgimento no cenário juridico

28 - Considerando que a concessão é ato juridico, cujádicos Considerando, ainda, que os atos juridicos, festação é ato de vontade, conse têm determinado conteúdo, e, consendo manifestação da vontade tên dividem siderando, finalmente, que, pelo conteúdo os atos jumbinação de amsiderando, finalmento pela combinaça de amem unilaterais e caráter complexo, separamos bos, formarem-se, ainda, os atos dédica de concessão de serviço púas correntes sôbre a natureza juridica de doutrinas unilaterais, 2) lico em três categorias fundamentais: 1) doutri

doutrinas contratuais, 3) doutrinas complexas.

29 - Os autores das teorias catalogadas na Estado, ao passo doutrinária dão maior importância à autoridade do Estado, ao patrique os autores das teorias catalogadas na segunda corticular enquanto quéria conferem maior deferência à liberdade do particúria procuram que os adeptos das teorias da última corrente doutrinaria procuram 
conciliar a soberania do Estado com a autonomia do particular:
Assim, as propostas para solucão da a posicões autoritárias solução da questão se prendem, no fundo possível harmonia entre ou libertárias, ou, estão, em tentativa de $\mathrm{Na}$.

Na primeira categoria doutrinária, há quatro teorias a se conato unilateral do concedenteral impôsto pelo poder público; b) a do. cípio como condição resolutiva e depoido pelo concessionário, a prinatos unilaterais: do concedente e do suspensiva; c) a dos dois. unilateral plural concedente e do concessionário; d) a do ato vontade do concedente e concessionário manifestação conjunta da

$\mathrm{Na}$ segunda categoria concessionário.

rias a serem examinadas: doutrinária, também, existem quatro teoconcedente examinadas: a) a do contrato de direito privado, entre dente e conseqüente contrato b) a do ato administrativo do concecessionário; c) a do contrato de direito privado entre êle e o conacordado entre concedente de direito misto: público e privado, direito público, entabolado entre concedio; d) a do contrato de

$\mathrm{Na}$ terceira categoria doutrinária ente e concessionário. três teorias fundamentais: a) a trinária, finalmente, se encontram contrato complementar a a do ato unilateral do concedente com o aspecto patrimonial do neó entre êste e o concessionário, regendo e concessionário, com ato unilateral a do contrato entre concedente nização e funcionam ato unilateral daquele, dispondo sôbre a orga cedente e concessionário do serviço; c) a do ato-união, entre conato unilateral do concedente, recendo a concessão, completado pelo do serviço, e contrato dente, regendo a organização funcionamento o aspecto patrimonial do negócio. o concessionário, dispondo sôbre

$$
\S 2 .^{\circ} \text { - As teorias unilaterais: }
$$

30 - Os prosélitos das teorias unilaterais entendem que a confestação de vontade ato do poder público, isto é, por simples manipode ser admitida do concedente. A vontade do concessionário sendo preponderante a vontade a complementar da concessão, Este outorga o servico público emanada do ato da administração. ser exercido determinada forma muito, aquiesce sôbre e condições por êle fixada, aquêle, quando gens econômicas que o exercício do serviço, tendo em vista vanta-

31 .

de império e dada a posicão prepe que ela decorria de simples ato ficava o concessionário posca preponderante do ato de autoridade quer manifestação de vontade, pró ou independentemente de qual- ponsabilidades do serviço, impostas pelo concedente. Em conseqüência, o ato da concessão gerava, apenas, obrigações do concessionário para com o concedente sem lhe conferir qualquer direito. Trata-se de teoria baseada em concepção autoritária do Estado e, por isso, havida como teoria política. Afirmavam que cumpria a todos os particulares, prestar serviços ao Estado, no interêsse da coletividade, quando não conviesse ao poder público prestá-lo diretamente.

Ao concessionário não seria, portanto, permitido o reclamar cousa alguma, nem mesmo pedir qualquer indenização por alteração superveniente no regime da concessão determinada pelo concedente, porque o poder público, transformando, restringindo ou revogando a concessão, sempre age no exercício do direito de soberania que lhe deve ser reconhecido, para, no seu alvedrio, dispor das concessóes de serviço público. É a teoria da coação legal.

32 - Posteriormente, atendendo ao fato de que o Estado jamais impõe a quem quer que seja a concessão de serviço público, constituindo, portanto, a teoria política da coação legal simples especulação no ar, sem base na realidade, fàcilmente conseguimos, independente de quaisquer requisições, atendendo, ainda, a que nos Estados de Direito, não é lícito se exija sòmente de determinadas pessoas o exercício de certa atividade, prescrevendo normas restritivas a alguns particulares, sendo, apenas, admissível se editem preceitos de polícia, de ordem geral, amoldando o exercício das liberdades, tanto no interêsse da coletividade como no do próprio Estado, - conclui-se que, para que o ato administrativo unilateral do concedente produza os seus efeitos, há necessidade de assentimento do concessionário, o que constitui condição de eficácia do ato.

A vontade do particular, pressuposto do ato unilateral, tem o alcance, conseqüentemente, de impedir que o ato de concessão produza os seus efeitos, isto é, tem função negativa. Ela consiste em mera condição resolutiva do negócio jurídico. Assim, não the dá vida; apenas se liga ou desliga pela aceitação tácita ou renúncia explícita.

Embora a vontade do concessionário não seja elemento constituidor do negócio jurídico, o qual é havido como criado, pela manifestação unilateral do poder público se reconhece ser a aquiescência do concessionário elemento para que tal negócio produza seus efeitos, oferecendo por essa sujeição voluntária, a condição conveniente a isso como elemento formal para a eficácia do ato unilateral do poder público. Assim, salvo disposição expressa em contrário, a data da concessão é a do ato unilateral do poder público, outorgando a concessão. $\bar{E}$ a concepção da submissão voluntária, na teoria do ato unilateral admitido. 
33 - Concordando em que na concessão o concedente não impõe obrigações ao concessionário, no exercício de ato de império, pois, nessa relação jurídica êste não se encontra em face daquele na posição de súdito e sim em estado de liberdade e, mais, que, para a eficácia do instituto jurídico, senão mesmo para a sua validade, é indispensável a manifestação autônoma da vontade do concessionário, entendem outros que a fonte geradora da concessão, decorre da manifestação de ambas as vontades: do concedente e do concessionário.

A vontade do concessionário não deve ser havida, entretanto, como tendo simples função negativa, consistente em submissão voluntária ao ato administrativo, porém como elemento positivo e de interferência ativa na concessão. Assim aparecem em tal instituto dois negócios jurídicos, com vida própria, si bem que não simultâneos: de um lado, manifestação da vontade do concedente, por ato administrativo; do outro manifestação da vontade do concessionário por ato privado ou público, segundo êste seja pessoa de direito privado ou público, isto é, particular ou autarquia, institucional ou territorial.

Os atos do concedente e concessionário se encontram, na frase dos adeptos dessa teoria, ligados entre si, sendo que o ato do concedente constitui a causa da obrigação do concessionário e o ato dêste, condição de emanação do ato administrativo, quando the precede e condição da sua eficácia ou mesmo, da sua validade, quando The sucede.

Apesar de intimamente compenetradas, essas duas declarações de vontade não se integram em um único negócio jurídico, permanecendo como dois negócios jurídicos aparte, embora ligados entre si, dada a diversidade de natureza das pessoas que os produzem e o fim dos atos de cada qual. É a teoria dos dois atos unilaterais.

34 - Uma vez que a manifestação de vontade do concessionário constitui simples condição da concessão, não deve ser havida como negócio jurídico, aparte do ato unilateral do poder público que a confere, pois, a manifestação da vontade do concessionário, aquiescendo na delegação de serviço público, não intervém diretamente na elaboração da relação jurídica, criando, conjuntamente com a manifestação do ato do concedente, a figura jurídica da concessão. Simplesmente não se opõe a tal situação e antes concorda com ela. De certo modo, corre o risco de se ver entre os adeptos das teorias convencionais, quem pretenda que para surgimento de relação jurídica se faz mister dois atos unilaterais como partes integrantes necessárias.

$O$ que se deve sustentar é que o ato do concessionário constitui condição suspensiva da eficácia ou, mesmo, da validade do con- cedente para surgir a concessão e não condição resolutiva, mas sendo cedente para a certo que a parte geradora da concessão é o do concessionário será fator forAssim, a manifestação de vontade do concessionário será fator formal, mas de ordem essencial, jamais acidental como se afirmara, para a perfeição do ato. Portanto, a menos que exista disposição para a perfeição do ato. Portanto, a da concessão é a do ato de aceitação, expressa em contrário, a data da concessão fo a deita. Eis a teoria do pelo concessionário, da outorga que lhe for feita. Eis a teoria do ato admitido em seu último estágio de evolução, aproveitados os ato admitio the fornece a teoria dos dois atos unilaterais. Constitui subsidios que the fornece a teora deorias unilaterais. É a concepção dominante entre os adeptos das teorias unilaterais. Ẽ

a concepção da vontade nece
de teoria do ato admitido.

5 - Houve ainda, quem sustentasse ser a concessão formada 35 - Houve ainda, quem sustentasse, do concedente e concespor dois atos unico negócio jurídico, sionario, que se fundem, entro constituindo ato unilateral, visto que ambas as vontá é o de realina constituição de um instituto jurídico cujo objetivo é o de realização de serviço público, fím do ato jurídico e de ambas as vontades unilaterais que o compõem, as. quais se integram com o propótades unilaterais essa finalidade de interêsse público. É a teoria do sito de alcançar essa finalidade de interesse público. Eutrina pode ato unilateral plural. Não teve grande difusão tal doutrina e pode ser havida como a primeira etapa nas especulações de alguns autoser havida complexa res, para che

36 - Sendo a concessão ato jurídico do concedente e constiuindo a aceitação dela pelo concessionário pressuposto da sua efitunndo a aceitaça deorias unilaterais administrativas, cáciád, declaram os adeptos das teorias unilaterais administrativas, ser óbvio que dêsse negócio jurídico, decorrem direitos e obrigaçoes. As obrigacões emanadas do ato administrativo da concessão, podem As obrigaçós cón modificanser, em qualquer epoca, regulamentadas pelo concedente, modicem do-se mesmo, por ato próprio, o seu conteúdo. Os direitos dizem respeito ao aspecto patrimonial previsto no ato administrativo da respeito ao aspecto patrimos necessários para o concessionário levar concessão e aos elementos necessários para o equilíbrio financeiro do a têrmo o serviço delegado. Ressalvado o equilíbrio financeiro do concessionário e outorgados os elementos necessários para exercício concessionario a tividades, tudo mais cabe ao concedente dispor livemente.

$$
30^{\circ} \text { - As teorias contratuais. }
$$

37 - O instituto jurídico da concessão, para os adeptos das doutrinas contratuais, surge de um acôrdo entre o Estado e o pardoutrinas contratuais, surge de um acôro elementos necessários, para ticular, cujâ 
a execução de serviço público que só por êle poderia ser exercido antes do ato da delegação. Êste recebe o encargo de desempenhar serviço público no interêsse da coletividade.

Há por conseguinte, fusão de vontades que gera relação jurídica contratual de direitos e obrigações recíprocos. Concedente e concessionário são, portanto, mútuamente credores e devedores de prestações em virtude de acôrdo feito sobre execução de serviço público, sob determinada forma e certas condições, o que estabelece entre êles contrato oneroso sinalagmático e comutativo.

38 - A princípio se entendeu que essa relação jurídica era de direito privado, sob a alegação de que o Estado, quando contrata com o particular, a êste se equipara, saindo assim, da esfera do direito público, para entrar no campo do direito privado, e, porisso, os vínculos estabelecidos se regem pelas normas do direito comum. Sustentou-se, enfim, que o contrato é a figura típica do direito privado como o tratado é instituto por excelência, do direito público. E a chamada teoria civilista, a qual, ao definir a figura jurídica da concessão, se apresenta sob vários matizes e vai, desde os que acharam que tal contrato de direito privado importava na transferência de um direito real do Estado para o particular, até os que reconheceram nêle simples criação de obrigação pessoal. Dada a dificuldade de se enquadrar a concessão em qualquer das modalidades contratuais previstas pelos códigos civis, mas, entendendo-se que êsse instituto só surge do acôrdo entre o Estado e o particular e que o contrato é figura peculiar do direito privado, passou-se a designá-la com contrato "sui generis" de direito civil ou como contrato inominado.

39 - Reconhecendo que jamais os preceitos de direito privado, poderão reger a organização e funcionamento do serviço público e sequer o exercício de poderes que tal atividade pressupõe, os quais são delegados pelo concedente ao concessionário, como os de polícia na esfera do serviço concedido e os de desapropriação de bens necessários a se integrarem no patrimônio da emprêsa concessionária para melhor consecussão de seu programa de ação e, ainda, a percepcão de taxas como contra prestação de serviço oferecido a terceiro, - houve autores que observaram ter a concessão a sua origem em ato de império resultante de complexo procedimento administrativo, isto é, ato administrativo unilateral, completado, no entanto, por ato de gestão, quer dizer, contrato de direito privado.

Ambos os momentos, entretanto, se integram para êles em um só ato para perfeição da concesão e se vinculam com direitos e obrirações recíprocas, previstos pelo ato da autoridade e concretizados no contrato adjecto, o qual altera a índole do ato unilateral e con- ciliando os interêsses coletivos e individuais faz com que a concessão se regule pelo critério da justiça comutativa. Surgiu assim a teoria mista do ato-contrato.

40 - Outros autores verificaram que, embora a concessão derive de ato de autoridade, êste, como reconhecem os expositores da teoria do ato-contrato, se reduz ao contrato, e só nasce com a perfeição do acôrdo de vontades. Portanto, o ato administrativo unilateral, na verdade, deve ser havido como manifestação da vontade lateral, na verdade, deve ser have com a vontade dos particulares do poder público que, fundindo-se com a vontade dos particulares no contrato de direito privado, disciptos. Logo não há ato-contrato, gando as partes e lhes conferindo direitos. Logo não há ato-contrato, mas simplesmente contrato. Porém, como o objeto dêsse contrato tem a sua parte inicial em ato de império do concedente cuja manifestação de vontade entrega ao concessionário poderes que refulnifestação de vontade entro objeto mesmo da gem do campo do direito privado e ainda como o objeto mesmo da concessão envolve normas de direito público relativa à organização e ao funcionamento do serviço, subordinadas à regência dos princí e ao funcionamento do serviço, subor sustentaram que o contrato de pios afetos a êste ramo do direito, sustento público.

Ponderando entretanto, que o c privado, rara regulamentar rélaçóes de utilidade econômica, mas privado, para regulamentar rimeiro que atendendo por sua vez ser a utilidade pública, o motivo primeiro que fundamenta tais relações e considerando, afinal, que a evolução do direito vem rompendo com a rigorosa distinção entre o direito púdire ve vóprios blico e privado com de ação, pois que, as relaçóes jurídicas hoje em dia dependem mùde astado e da autonomia dos particulares, tuamente do de forma réíproca a êles, arrematam que na verdade interessando de forma recíproca a eles, arre misto, não estabelecendo a ato de concessão deve ser havido como misto, não estabelecélico e privado.

41 - Embora se aceite a título de argumentação, se não tenha estabelecido princípio de caráter abstrato geral, distinguido de forma estois ramos fundamentais do direito: áblutamente satisfatoria os dois rinda, a unidade científica do sapúblico e privado, e ramos fundamentais do direito situaçóes diversas e permitem se prefigure regime diferente, formando duas províncias nítidas nos trabalhos especulativos e práticos. E daí concluem os modernos contratualistas pelo absurdo e praticos. E dai concluem os contrato misto, o que implicaria em se criar, da susção entre em vez de se abolir, como dizem os seus adeptos, direito misto. Ino- dón liás, sem fundamento lógico, por não saberem os seus pró- 
prios inventores qual o conteúdo, composto de elementos dos outros os dois ramos do direito nãodeira contradição de têrmos, pois, se rem as dúvidas, como admitir se distinguem a ponto de desaparecementos próprios derceiro ramo, misto, formado de elecada um dos outros dois, e misto, justamente por envolver nas suas relações elementos, e misto, justamente, dêles? Ora, se os outros têm elementos peculiares de cada um acentua bem preceitos tém elementos peculiares e se a relação proprios de cada um daqueles ramos de dique se distinguem perfeitamente, apesar ramos de diencontrado (admita-se para discutir) regra, apesar de não se have enuncie, de modo justo, essa ditiñ , regra geral satisfatória, que jurídica.

Entendem que o êrro da concepção provém de duas razōes fundamentais: a) suposic̃̃o de que o contrato direito privado; b) defeituosa interpretaco seja figura exclusiva do ções do direito público, existirem preceito do fato de, nas relaaos das relações de direito privado preceitos iguais ou semelhantes

Uma vez que o contrato pode ser conceituado pelos seus característicos essenciais, de forma distinguílo de outras seus caracatos jurídicos, e já se chegou a distingui-lo de outras figuras de não é crivel se pretenda classificação satisfatória dêstes, instituto próprio de não é figura pra saber jurídico. O contrato, em não é fligura peculiar nem do direito privado nem do direito, em si, mas uma das classes fundamentais priva nem do direito púbo, abstratos e gerais são contornos proceder à classificacão fornecidos pela teoria geral do Direito, ao.

Se a dos jurídicos.

contrato e não jurídica não houvesse estabelecido o conceito do ses fundamentais de atos jurídic sistematizado como uma das clastípicas de contratos atos jurídicos, mas, apenas, conhecesse figuras xados em requisitos definidos pelos seus característicos especiais, fiadmissíveis as figuras de conceituavam, então, só seriam lação jurídica contratual contrato estritamente previstas e cada reum dos tipos padróes. $F$ necessariamente cumpria se amoldar a no direito privadroes. E se êsses tipos padróes só fôssem previstos era figura de direito privado a sustentável a tese de que o contrato fícuo, dos doutrinários, de enquadrar os aria o trabalho, aliás, improdireitos e obriona estabelecidos.

A inteligência humana, porém, não se satisfaz com as soluções. práticas em que os casos são resolvidos atendendo a razões puramente. a retirar dá ordenando o seu saber. Assim, na ciência jurídica, além das hipótoses, há às teses.

Portanto, onde há acôrdo de vontades gerando relaçôes jurídicas opostas, surge a figura do contrato. E tal se dá, tanto no direito privado, civil e comercial, como no direito público, interno e externo. $\mathrm{Na}$ esfera externa ou internacional, contratam os Estados entre e com outras pessoas jurídicas, físicas e coletivas, na interna ou nacional, também, o Estado e as pessoas jurídicas de direito público, que são seus desmembramentos, seja por descentralização territorial ou por descentralização de serviços, as quais constituem entes autárquicos, contratam entre si e com os particulares, realizando acordos de vontade que os vinculam a relações jurídicas do mesmo gênero das firmadas entre particulares, exclusivamente, nas suas relações recíprocas civis ou comerciais. $\mathrm{Na}$ primeira hipótese temos contratos de direito público, interno ou externo, e, na segunda, contratos de direito privado, civil ou comercial.

Por se encontrar no direito público normas iguais ou semelhantes às de direito privado não se pode pretender, em absoluto, que as regras dêste estão sendo empregadas em relações daquele, pois, 0 fato de distinguir-se a ciência jurídica em dois ramos fundamentais não implica em exigir-se que êles tenham regras exclusivas. E, assim, se não deve conceituar como sendo de relação mista de direito público e privado, àquêles em que concorrem preceitos havidos como próprios de cada um, por se encontrarem, em geral, classificadas, nas relações jurídicas, como dêste ou daquele ramos.

O direito público, como o direito privado, são ramos da ciência jurídica, e, por isso, as relações de ambos devem ir procurar no tronco de onde descendem as normas para regência dos seus institutos. Nada há de estranhável que, em muitas relações de direito público existam regras que se encontram em relações de direito privado, visto que situações iguais ou semelhantes devem ser reguladas: por preceitos iguais ou semelhantes. Atribui-se ao direito privado muitas normas, porque se verificou ter sido empregado em primeiro lugar nas relações entre particulares, mas essa circunstância não constitui base sólida para disciplinar-se o ato jurídico abstrato, que serve de "substratum" do instituto concreto, como pertinente ao, direito privado, mas a regra que permite essa relação, em princípio, não pertence privativamente a êste ou àquêle ramo, mas ao direiton em geral. Se a relação proposta visa reger relações entre entes públicos, entre si ou entre êstes particulares, na consecução de finalidades coletivas, ela é de direito público; se, ao contrário, rege rela-ções entre particulares ou entre êstes e entes públicos, na realização de finalidades particulares, é de direito privado. 
Assim, sendo, a concessão de serviço público um ato jurídico pelo qual o poder público se despoja de atribuição que lhe é peculiar a confere a terceiro, no intuito de melhor tivo e não ao jas partes em jốo é vontades havido, vinculando cíprocas é de direitos e obrigações reciprocas é de direito público. Ao invés do Estado descer do direito privado, como querem os adeptos da teoria civilista, é de se pretender que o particular ascenda à esfera do direito público, para contratar com o poder público. Presentemente, entre público, tratualistas, a teoria dominante é a do contrato de direito público.

$$
\$ 4 .^{\circ} \text { - Discussão das doutrinas unilaterais e contratuais. }
$$

42 - Embora a natureza jurídica da concessão venha sendo objeto de grande debate entre os mestres, êles reconhecem, presentemente, que ela deve ser regida pelos princípios de direito administrativo Estão em absoluto déción direito admivamente, ficavam a respectiregidas pelas normas de direito civil ou eram inim, constituem mera reminiscência histórica as teorias de concessão como contrato de direito privado e como ato de coação legal.

43 - Conceituando a concessão como ato unilateral do poder público, os partidários desta corrente doutrinária esbarram em sérios entraves, ao contrário do que acontece aos publicistas que sustentam as teorias contratuais quande prociram as teorias contratuais, quando procuram explicar as consequiências da doutrina, com relação aos vínculos entre concedente e concessionário, ou melhor, aos direitos e obrigações recíprocos. Por sua vez os defensores das teorias contratuais ficam em verdadeiro impasse para justificar a regulamentação da organização e funcionamento do serviço pelo concedente.

Entretanto, - afora os partidários das teorias privativistas que sustentam ficam as partes contratantes prêsas aos dispositivos ríg que das cláusulas expressas do contrato e estabelecem dispositivos rígidos nentes à concessão são exclusivame constantes prescritas por êle e dêle listas, como, de tôdas as outras teorias não só unilatera listas, como, mesmo, contratualistas, salvo o pronunciamento contraditório de certos autores, admitem a regulamentação da concessão pelo concedente, uma vez resguardada a estabilidade financeira do concessionário, sob o fundamento de ser ela regida pelos princípios de direito administrativo e estar instituida para satisfação de interêsse público. Por sua vez, excetuados os paladinos das teorias da coação como unilatera listas, admitem que da concessão surgem direitos e obrigações recíprocos às partes: concedente e concessionário. Os contratualistas
Sundamentam tais direitos e obrigações no contrato e os unilateraListas no argumento de que a relação é formada de atos jurídicos.

A concessão, embora outorgada por ato unilateral do concedente, tem a sua eficácia condicional à vontade do concessionário, a qual se manifesta pró ou contra, segundo as suas conveniências, tendo aem vista as vantagens econômicas que pela execução do serviço the são asseguradas pelo ato unilateral. Assim, a aceitação gira a favor do concessionário os direitos de ordem patrimonial oferecidos pelo concedente. Trata-se de ato jurídico do qual emanam direitos e obrigações, assegurando-se as posições das partes nêle envolvidas.

44 - Entendem os contratualistas que se o concessionário não se acha em posição de inferioridade em relação ao concedente e se lhe reconhece que a manifestação livre da sua vontade constitui elemento indispensável para validade, ou, ao menos, eficácia da concessão sendo que a efetivação dos direitos e obrigações do concessionário para o concedente depende da sua declaração, como, também, a dos direitos e obrigações dêste para aquêle, depende, também de sua declaração - é porque as vontades de ambos se integram, assumindo direitos e obrigações recíprocas, mediante o concenso contratual.

Não padece dúvida que, concluem êles, dois consentimentos, por si sós, não são elementos suficientes para gerar contrato, mas se êles se fundem pela criação de deveres e obrigaçôs recíprocos, vinculando as relações entre as partes temos, inegàvelmente, a figura jurídica do contrato.

45 - Argumentam os unilateralistas ser impossível o contrato, dada a diversa natureza jurídica dos dois sujeitos na figura da concessão, pois, a constituição de um serviço público não pode ser formada por duas vontades que se contraponham com interêsses divergentes, visto que êle é instituido para servir o interêsse coletivo, e, assim, acima dos interêsses das partes cumpre, sempre, se tenha como objetivo principal o interêsse público.

O contrato, continuam, tem como sua função específica a troca de utilidades econômicas em regime de liberdade e igualdade, ao passo que a delegacão do exercício de um serviço público tem por principal objeto o próprio serviço público, o qual está fora do comércio e por conseguinte não pode constituir objeto daquela relação jurídica. Em regra, o regime da concessão e em particular a organização e funcionamento do serviço público é ditado pelo concedente, com completa ausência de intromissão do concessionário, ao qual é, muitas vezes desconhecida a faculdade de discutir as normas da concessão, tanto na sua formação como na sua execução.

Atendendo-se finalmente a que o fim de qualquer serviço público é o de servir aos interêsses da coletividade, não se pode desconhecer 
o preceito máximo impôsto pela sua essência, isto é, a exigência de sua adaptação de forma a, cada vez mais, atingir o seu escopo e conseguintemente o direito de o Estado determinar o seu aperfeicoamento alterando as condições da sua exploração, sempre que julgado conveniente. Por haver delegado o exercício de determinado serviço público a terceiro êle não pode perder essa prerrogativa que é caraterística dêle e nem a concessão do serviço se compreende tenha sido feita com outro objetivo que não o de servir o público satisfatòriamente: Logo, se o regime do serviço público está sujeito às regulamentações do poder público, a quem cumpre aquilatar as maneiras de como melhor resguardar o interêssé coletivo, não se pode de forma alguma falar em contrato de concessão, pois, se êste existisse, as clausulas relativas à exploração do serviço não poderiam ser impostas e modificadas por uma das partes contratantes. De concluir, a concessão é ato unilateral do Estado.

46 - Replicam os contratualistas que para existir contrato se exige apenas sejam as partes pessoas capazes de direitos e obrigações, feito aquêle na forma legal e com objeto lícito. Por conseguinte não requer igualdade quanto à natureza das pessoas contratantes, sendo pois admissível perfaçam os particulares contratos com o Estado, os quais serão de direito público ou privado, conforme a regência do conteúdo dêle, isto é, as obrigacões estipuladas se refiram a êste ou àquele ramo da ciência jurídica. Negar-se a possibilidade do Estado contratar com particulares sob o fundamento de serem êstes de natureza diversa, é desconhecer a realidade das coisas, visto que quotidianamente assistimos a contratos administrativos de empréstimos, mediante emissão de títulos, e contratos civis de locação de imóveis para instalação de repartições públicas, entre o Estado e particulares. Aliás, a essência das pessoas é diferente, quanto à natureza, mesmo no direito privado e daí classificarem-se em pessoas privadas, físicas e coletivas.

A expressão "coisa fora do comércio" significa a impossibilidade de constituir o bem, assim classificado, objeto de contrato, ou, melhor, significa ser êle inalienável. Mas, na concessão, não há alienação de serviço público, nem sôbre êle se contrata, apenas o exercício de determinada função é delegada a terceiros, consistindo, portanto, em simples contrato sôbre a forma de prestação de certa atividade com a conseqüente outorga dos poderes necessários para que ela se efetive. $O$ servico público a ser instituido, é a conseqüência simplesmente do contrato que regula exclusivamente o modo de seu exercício e confere os meios convenientes para isso. Aliás, a declaração de incomercialidade de certos bens e a proibição de serem alienados e conseqüentemente de serem objeto de comércio, visa obstar que se perfaçam relações jurídicas prejudiciais ou mesmo contrárias ao seu destino. Não pretende, porém, impedir que se estabeleçam aquelas que estão em consonância com o destino dêsses bens e procurem lhes permitir o oferecimento de maiores utilidades e satisfação de melhores interêsses. Nada impede por sua vez, dizem ainda, que em regra as cláusulas da concessão sejam prefixadas pelo concedente com absoluta ausência de ação do concessionário, ao qual é negada a liberdade de ajustar as condicões do comércio. E isto porque, uma vez haja acôrdo de vontades sôbre elas, seja acertando em comum as suas teses, seja apenas aderindo às bases formuladas por uma das partes, integrando-se a respeito das relações recíprocas, - há o contrato.

Finalmente, consideram que os serviços públicos se devem daptar às novas condições sociais e se aperfeiçoar segundo as exigências públiças, entendendo qué tal em nada prejudica o contrato, embora a regulamentação do serviço seja prescrita, à medida das necessidades, livremente, pelo concedente, na defesa do interêsse público, visto como o contrato é de natureza pública (senão totalmente, ao menos, de forma parcial), sujeitando-se, na sua aplicação, a normas diferentes das dos contratos de direito privado. Aliás, se diversidade material não existisse entre os contratos públicos e privados, nada justificaria a distinção feita. Assim, desde que assegure a estabilidade patrimonial do concessionário, nada impede o Estado de exercer o seu império sôbre a organização e funcionamento do serviço, pois, o contrato existiu formalmente para perfeição do acôrdo de vontades e continuará a existir enquanto o seu aspecto fundamental, isto é, de troca de utilidades econômicas, não for rompido ou burlado por uma das partes. O engano dos unilateralistas está em pretender que os contratos de direito público ou, ao menos, sujeitos a normas próprias do direito administrativo, se submetam, na sua vigência, às mesmas condições previstas para a execução dos contravigência, às mesmas condiçoes previstas para a expressão "contrato de direito tos de direito privado. Ademais, se a expressão "contrato de direito "ato bilateral", no qual a vontade de duas partes acordantes e opostas se integram assumindo direitos e obrigações recíprocos, relativos à execução de serviços públicos.

47 - Voltam à carga os unilateralistas afirmando que se não nega a posibilidade de contrato entre o Estado e o particular, mas se nega a possibilidade de existir contrato na concessão, porque a se relação ao instituto não permite que se ajustem as duas vontades, em contrato, cujo objeto é o de qatisfazer interêsses divergentes e, no caso, o que se procura é exatamente e conjugação das vontades para satisfazer interêsses convergentes - o bem da coletividade na instituição de um serviço público.

$28 \mathrm{a}-$ R. D. $-20^{\circ}$ Vol. 
Demais, não é verdade que o serviço não seja objeto de concessão e sòmente o seja a maneira de seu exercício, pois, pela concessão se estabelece, na verdade, a instituição de um serviço público, cuja execução deverá ser levada a efeito, de tal modo. Assim o próprio serviço é objeto de concessão e estando êle, pela própria natureza, fora do comércio, isto é, não sendo suscetível de transação ou troca de utilidades econômicas, não se compreende se classifique a concessão como contrato. E' de notar-se, além disso, que se uma cousa é havida como inalienável, não há que se justifique a distinção ante a possibilidade de ser ou não, objeto de relações jurídicas, segundo estas são estabelecidas em atenção ou não ao seu destino, pois, a inalienabilidade deve ser absoluta, isto é, ou o bem é alienável ou não o é, enquanto conserva determinada natureza.

Ainda, falar em contrato de adesão é negar o contrato, pois, êsses dois têrmos "hurlent de se trouver ensemble". De fato, o contrato pressupõe integração de vontades com referência à relação jurídica e tem por conteúdo e fim a satisfação de interêsses opostos, em que as partes livremente debatem as suas cláusulas, o que, certamente, falta no pseudo contrato de adesão e falta porque não se fundem realmente suas vontades, havendo simples manifestação unilateral de duas vontades: a primeira outorgando a concessão e a segunda aceitando-a. A adesão de um ato jurídico objetivo não é suficiente para transformar essa relação em contrato, pois, nem todo acôrdo de vontades deve ser havido como tal. Para que êsse exista é necessário que as partes, acordando sôbre os conteúdos opostos, cada um satisfazendo intetêsses próprios, estabeleçam, diretamente, situação jurídica subjetiva nova, seja ela modificacãão da situação jurídica anterior ou, então, pela criação mesmo, de outra situação jurídica. Não se pode mudar o conceito do contrato tradicional desde o direito romano para enquadrar ou procurar enquadrar dentro dêle a figura da concessão. Se esta não pode ser havida como contrato, dentro do conceito clássico dêste, o razoável é modificar êsse conceito, mas, enquadrar o instituto em outra figura jurídica.

Por fim, admitir que a concessão, sendo um contrato de direito público, seja suscetível de regulamentação e assim seja lícito ao poder público adaptá-la, segundo o interêsse público, é, na verdade, negar a existência do contrato, pois, se neste as duas vontades se integram, não se pode permitir, após a fundição dessas vontades sôbre determinado objeto por uma das partes. Aliás, o afirmar que os contratos de direito público devem se reger, apenas formalmente, por formas idênticas às de direito privado e materialmente por normas diversas, é justamente aceitar que a concessão não se pode reger pelo contrato, pois, as normas fundamentais que regulam êsse instituto jurídico devem ser, sempre, as mesmas, tanto no aspecto formal como material, visto que o seu conceito é fornecido pela teoria geral do direito, sendo que a distinção entre contrato de direito público e de direito, sendo que a divado deve estar, apenas, no objeto e fim da relação jurídica. reito privado deve estar, apenas, no objética, chegam até a substituir De fato, certos autores para evitar a crítica,

a expressão "contrato" pela de ato bilateral. fonte direta no acôrdo de vontades entre concedente e concessionário, mas, na lei editada unilateralmente pelo Estado e que pode ser por êle livremente modificada sem qualquer interferência do particular, alterando o modo de organização e funcionamento do serviço, segunalterando o modo de organização e funcione em absoluto, chamar de do as convenienciço contrato o acôrdo de vontades sôbre execução de determina atribuição e espúblico, pelo qual uma das partes entrega à outra tal atribuiçáo ta se obriga a executá-la, segundo as prescrições daquela, isto é, a submeter-se aos textos legais promulgados ou a se promulgarem, sôbre a organização e funcionamento do serviço. Não é possível o contrato sobre objeto indeterminado.

\section{$\$ 5 .^{\circ}$ - Teorias complexas}

48 - Pelo exposto se verifica que ambas as correntes doutrinárias são deficientes e a discussão continuaria, entre unilateralistas e rias são deficientes em resultado prático, se não aparecesse nova corrente doutrinária.

Procurando solver êsse impasse criado pela divergência entre unilateralistas e contratualistas, e reconhecendo que ambos os lados unilateralistas de razão, foi arquitetada a doutrina complexa que tinham parcelas de razão, fosções em choque e por têrmo ao deprocura harmonizar as duas posiçóes em choque

49 - Sustentou-se, então, que a concessão é, na verdade, um instituto jurídico complexo, no qual há duas operações distintas e fundamentais: o ato unilateral regulamentando a organização e funcionamento da concessão, e o contrato regendo o aspecto econômico do negócio.

Essa teoria, é preciso esclarecer, não se confunde com a do atocontrato, embora tenha ido, sem dúvida, beber na sua fonte a idéia da solução proposta, a qual, foi, entretanto, completada com os elementos fornecidos pela discussão havida entre as correntes opostas: unilaterais e convencionais, em as suas recentes modalidades teóricas.

Dizemos que se não confunde com a teoria do ato-contrato, por que esta, na verdade, reduz a concessão a um verdadeiro contrato, como proclamam os seus adeptos, ao passo que a teoria em aprêço entende que os dois atos jurídicos: unilateral e contratual, têm vida entende que os dois atos jurídicos: unilateral e contratual, ter juas distin- 
tas. Daí, afirmarmos que foi esclarecida pelos argumentos expendidos nas discussões havidas entre unilateralistas e contratualistas

Distinguindo-se na concessão dois elementos essenciais, condicionados um ao outro, sem se fundirem, encontram, os adeptos desta teoria, dificuldade em explicar quando surge a concessão.

50 - Alguns entendem que ela surge com o ato unilateral e, apenas, se aperfeiçoa, para efeito de execução, com o contrato complementar, anexo ao ato de concessão, o qual constitui, assim, simples condição de eficácia do ato unilateral. O contrato é o meio pelo qual se obtem a cooperação do concessionário e concerne ao arranjo financeiro da concessão, sendo que aquêle, ao firmá-lo, se dispõe à organização e funcionamento do serviço, desde que a sua estabilidade econômica fique assegurada nos moldes contratados, única cousa, aliás, objeto do contrato.

51 - Outros pensam que a concessão surge do contrato, pelo que se acorda a instituição de um serviço público, mas, como o contrato só rege as relações de ordem patrimonial, respeitantes ao seu objeto, a administração não perde a sua situação legal de poder público... Por isso, o contrato deve dispor sòmente sôbre os assuntos da alçada que lhe é própria e não sôbre a matéria de ordem legal. Na hipótese, entretanto, de enfeixar nas suas cláusulas tais assuntos, não se pretende, com isso fixá-los na rigidez do contrato, pois, pela sua natureza flexível, a êle não podem, em absoluto, estar sujeitos. Entenderse-á, em tais circunstâncias, como implícito nos têrmos do contrato, - que regula a instituição de um serviço público e o seu aspecto financeiro - quando não houver dispositivo expresso, que as matérias de ordem legal são susceptíveis de alterações regulamentares contratuais.

A regulamentação da organização e funcionamento do serviço é feita unilateralmente pelo concedente, não pelo fato de ser a concessão contrato de direito público, e, por conseguinte, devam aquelas cláusulas contratuais ser amoldadas, pela administração, segundo as necessidades e conveniências públicas, mas porque envolve a situação legal do serviço, matéria regulamentar fora do contrato.

52 - Por não se haverem apercebido da "nuance" entre as con' cepções dêsses autores que conceituam a concessão como ato complexo, mas explicam de forma diferente o momento da constituição da concessão, - há escritores que, ao classificarem as doutrinas sôbre a concessão, colocam os primeiros como partidários da antiga e obsoleta teoria do ato-contrato e os segundos como adeptos da teoria do contrato de direito público, quando, conforme expuzemos, isso se não dá.
De fato, para os partidários de ambas essas teorias, a concessão enfeixa dois atos jurídicos com vida própria, a saber: o ato do poder público, unilateral, que estabelece a organização e funcionamento do servico, a sua situação legal; e o contrato oriundo do acôrdo de vontades, que rege o aspecto patrimonial do negócio, a sua posição econômica individual.

Ambas as teorias, no entanto, não podem explicar como êsses dois atos, unilateral, regendo a organização e funcionamento do serviço, e contratual, dispondo sôbre o aspecto patrimonial dêle, se condicionam um ao outro sem se fundirem, se integrando no instituto complexo da concessão. E' que, para estabelecer tal relação jurídica, há necessidade de outro ato, ato êsse que condiciona a aplicação das normas objetivas da organização e funcionamento do serviço, às situacões subjetivas surgidas do acôrdo entre concedente e concessionário. Daí a necessidade de nova teoria para solver a incógnita.

53 - Então, surge a nova concepção daqueles que entendem que $o$ a to jurídico instituidor da concessão não é nem ato unilateral, nem um contrato, e sim ato-união pelo qual se acorda a instituição de um serviço público, que será explorado nos têrmos regulamentares prescritos por ato unilateral do concedente, garantida ao concessionário a estabilidade econômico-financeira da emprêsa, nos moldes fixados pelo contrato complementar ao ato de concessão.

O serviço público, cuja exploração por terceiros fôr acordada mediante ato-união, será levado a efeito pelo concessionário, dentro das normas legais vigentes na matéria, editadas pelas entidades políticas competentes e na forma regulamentar estabelecida pelo concedente, com as modificações introduzidas, unilateralmente, no curso da exploração do serviço e exigidas pelo interêsse coletivo, assegurada, sempre, no entanto, a equação econômico-financeira do concessionário, fixada pelo contrato, complementar ao ato jurídico pelo qual se acordou a concessão.

O contrato regula as cláusulas relativas ao "quantum" da renda a ser auferida pela prestação do serviço, bem como as que reflexamente possam influir sôbre êle, a saber: as que outorgam privilégios e regalias aos concessionários, fixam os prazos e forma de início e extensão da concessão e regem as condições de indenização por ato regulamentar do concedente.

Pelo ato-união, as partes acordam a instituição ou, ao menos, a execução de determinado serviço público, assumindo direitos e obrigacões $O$ concedente concorda em entregar ao particular certo serviço, com o fim de vê-lo desempenhado da melhor forma possível, sem desembôlso de grandes capitais e, assim, se supre deficiência até então existente na vida administrativa e, por sua vez, se obriga a the conferir os meios públicos necessários para isso, e o concessioná- 
rio concorda em executá-lo com o fim de obter certa remuneração julgada satisfatória em função do capital empregado na instalação e funcionamento do serviço e, por seu lado, se obriga a levá-lo a efeito no interêsse coletivo, como serviço público que é.

Assim, além do ato-união que firma o acôrdo de execução do serviço público, há o ato unilateral fixando a situação objetiva do serviço relativo à sua organização e funcionamento, e o ato contratual, regendo a situação subjetiva dêle, a qual compreende as relaçōes de ordem patrimonial, bem como o modo, a forma e as condiçóes de execução do serviço que repercutem diretamente sôbre a situação econômico-financeira da concessão. Cada um dos atos jurídicos referidos dispõe sôbre os assuntos da alçada que lhes é peculiar e, todos, com o campo de ação próprio, se encontram no instituto jurídico, complexo, que é a concessão. Embora materialmente a concessão pressuponha vários atos jurídicos, nada impede que, formalmente, êles se enfeixem em um único documento, compreendendo o acôrdo havido para a execução do serviço público e os princípios em que se acordou essa execução. $O$ documento escrito pelo qual se exterioriza um ato jurídico não tem a faculdade de modificar a natureza dos elementos que o integram.

A instituição do serviço público concedido se assemelhà, na sua estrutura jurídica, à instituição da família. Pelo ato-união duas pessoas acordam em se casar e instituir uma família, nos têrmos prescritos unilateralmente pelo Estado, sujeitando-se às alterações legislativas supervenientes. Querendo, porém, garantir a situação econômica do casal, podem contratar sôbre o regime de bens, dispondo como melhor julguem ficar acautelados recíprocos interêsses.

Portanto, a concessão se institui mediante o ato-união em que ambas as partes concordam em estabelecer determinado serviço público, assumindo o concessionário a obrigação de levá-lo a efeito no interêsse coletivo, satisfeita a sua situação econômico-financeira, fixada no contrato, e aceitando o concedente a obrigação de outorgar ao seu delegado os elementos necessários à execução do serviço público e garantir a equação econômico-financeira, exercido aquêle, segundo o bem público, prescrito por ato regulamentar.

As obrigações que, nascendo do acôrdo estabelecido entre concedente e concessionário, a fim de realizar o serviço público, se re sumem em um compromisso de colaboração leal e recíproca, pelo qual ficam, ao mesmo tempo, reconhecidas, mediante atos jurídicos competentes, a garantia do equilíbrio financeiro do concessionário e a possibilidade das prestações, segundo as normas regulamentares. A estabilidade econômica do concessionário se assegura por preceitos rígidos e as condições de organização e funcionamento do serviço os- cilam, conforme as conveniências públicas, adaptando-se às suas necessidades variáveis.

Assim, as relações de ordem patrimonial, relativas à execução de determinado serviço concedido, regem a posição econômico-financeira do concessionário, com direitos e obrigações referentes ao serviço acordado; e as relações de ordem legal, relativas à organização e funcionamento estável do serviço sôbre bases tarifárias razoáveis, regem a posição regulamentar do serviço acordado.

$O$ poder público não se despoja das atribuiçôes que lhe são peculiares e que justificam a sua razão de ser, pelo só fato de outorgar a particulares, mediante acôrdo, a execução de determinado serviço público, cuja regência deve sempre ficar subordinada ao seu fim específico: satisfação do bem estar da coletividade. O particular, por sua vez, ao se obrigar a exercer determinado serviço público, conforme o interêsse coletivo ajuizado pela administração pública, não fica em posição de inferioridade, porque livremente acordou na execução do serviço, dentro da equação econômico-financeira por êle contratada.

54 - Com a doutrina do ato complexo, na sua forma mais perfeita, isto é, que entende ser a concessão instituida por ato-união, mas regida por regulamento unilateral do concedente e completada por contrato patrimonial, se dissipam as dúvidas suscitadas pelas correntes unilaterais e convencionais, se conciliam as posições e se explicam perfeitamente todos os aspectos da concessão.

Realmente, o concedente e o concessionário, ao acordarem ambos a instituição do serviço público, têm as vontades solicitadas por idênticas causas intrínsecas, ou seja: a relação jurídica se firma, para se criar serviço público, pelo qual se satisfaçam os interêsses coletivos. A causa final, porém, é diferente: o concedente visa dar methor forma para se atingir a causa formal do acôrdo, o concessionário visa obter determinada posição financeira, na execução da causa formal do acôrdo, satisfazendo, no entanto, ambos, tal conteúdo, que, como salientamos, é o de instituir um serviço público.

O interêsse do concessionário se cifra em obter lucros na exploração do serviço e foi tendo em mira esta causa final que acordou em aceitar a concessão de serviço público, enquanto o interêsse do Estado $\&$ atender às necessidades coletivas na forma que lhe parece mais conveniente e considerando esta causa final, acordou em delegar a terceiro a concessão de serviço público. Assim, a concessão é originada de acôrdo, por conseguinte, convencional, mas não contratual. Para, porém, assegurar a sua posição financeira e atingir o fim pelo qual acordou em levar a efeito o serviço público, o concessionário firma contrato que estabelece a sua equação econômica. Por sua vez, o serviço público, pelo fato de sua execução haver sido entregue a 
um particular, não perde o caráter de serviço público e, por conseguinte, não se despoja o Estado das suas prerrogativas de prescrever, unilateralmente, as normas mais aconselhadas para o seu bom desempenho no interêsse coletivo, como juiz, que é, dêsse interêsse..

Fica, perfeitamente, explicada a razão da regulamentaçăo e defendidos os direitos e obrigações das partes.

O objeto da convenção é instituir um serviço público, o qual precisa de ser levado a efeito dentro dos moldes mais convenientes. ao interêsse coletivo, competindo à administração, na qualidade de poder incumbido da vigilância daquele interêsse, prescrever as. normas julgadas mais aconselhadas a fim de se atingir tal objetivo.

O fim que tem em vista a administração, ao firmar a convenção, é realmente êste: o de escolher entidade capaz de realizar proficientemente determinado servico público, a quem delega atribuição que lhe é peculiar e lhe assegura determinada vantagem econômica. E isso precisa de ser respeitado. Por outro lado, o fim que tem em atenção. o concessionário ao aderir à concessão é o seguinte: executar certo serviço público, mediante a inversão de determinado capital e organização adequada de emprêsa, a fim de obter um lucro compensador pela prestação de tais atividades, satisfazendo, no entanto, o interêsse coletivo nos moldes previstos pelo poder público. $\mathrm{E}$ isso, também, precisa de ser respeitado.

$O$ direito de exercer a concessão constitui um direito único e não vários direitos dos quais irradiem ás faculdades que dos atos administrativos (legais ou regulamentares) promulgados ou ordenadas pelos órgãos competentes, - seja antes da concessão, ao se fazer a. concessão ou ainda depois dela, - são atribuidos ao concessionário. Tôdas essas faculdades são instrumentos conferidos ao conces-: sionário para exercer o serviço público que se, por um lado, é um. direito dêle, por outro, é uma obrigação que lhe pertence, ou mais, lhe incumbe, uma vez que assumiu tal encargo. Assim, o concessionário possui tais faculdades enquanto são, pela administração, julgadas. úteis para êle cumprir o serviço público, como mero meio a se atingir aquêle fim.

As alterações na organização e funcionamento do serviço não acarretam qualquer dano ao concessionário, uma vez se lhe assegure a equação financeira estabelecida pelo contrato e, entretanto, aquelas medidas permitem à administração prover ao interêsse coletivo, segundo as circunstâncias que se apresentam.

$O$ interêsse privado deve, sempre, ceder diante do interêsse público. Sôbre êste só prevalece o direito privado, cuja segurança contra aquela está na reparacão patrimonial dos danos sofridos. Ante o interêsse coletivo, o titular de direito privado tem direito, apenas,

\section{$-899-$}

à sua conversão em determinada expressão patrimonial. Êsse o princípio que rege o direito público, e, portanto, os serviços concedidos

Sôbre a tese do professor Bandeira de Melo emitiu parecer a comissão competente, sendo relator o sr. João Abreu. Concluiu o parecer pela aprovação da tese, na parte em que vê, na concessão, negócio jurídico contratual. Sustentou, contudo, não se lhe afigurar plenamente satisfatória, no seu conjunto, a explicação oferecida pelo ilustre administrativista no identificar, quanto ao complexo de relaçōes intercedentes entre concedente e concessionário, a natureza jurídica da concessão de serviço público.

Pôsto em debate o parecer, em plenário, foi êle aprovada. 